TRIDARMA: Pengabdian Kepada Masyarakat (PkM), 5 (1) (2021) 10-21

\title{
Pemanfaatan Google Classroom Terhadap Siswa Pada Masa Pandemi Covid-19 Di Yayasan Rahmatan Lil- Alamin Jakarta Timur
}

\author{
Ryfhaza Rodia Rachman ${ }^{1}$, Dapitandi Saputra², Rizieq Zikrila³, Tuti \\ Haryanti ${ }^{4}$
}

Sistem Informasi,

Universitas Nusa Mandiri, JI. Raya Jatiwaringin No.2, Jakarta Timur, DKI Jakarta, 10450

Email: 1.ryfhazana70@gmail.com 2.dapitandi.saputra@gmail.com 3.riziqzkrl@gmail.com

4.tuti@nusamandiri.ac.id

\section{Abstrak}

\begin{abstract}
Permasalahan pada Yayasan Rahmatan Lil-Alamin Jakarta Timur yakni adalah belum menggunakan Google Classroom untuk media pembelajaran dalam jaringan, selama ini kegiatan belajar mengajar berlangsung dengan media komunikasi seperti WhatsApp group atau email. Luaran yang diharapkan yaitu menambah pengetahuan serta meningkatkan kemampuan siswa-siswi dalam penggunaan aplikasi digital khususnya Google Classroom untuk menunjang kegiatan belajar mengajar yang dilakukan secara dalam jaringan pada masa pandemi Covid-19. E-learning adalah perangkat pendidikan berbasis komputer atau sistem yang memungkinkan untuk belajar di mana saja dan kapan saja. Secara umum internet merupakan jaringan komputer yang luas dan besar yang di dalamnya terdapat berbagai sumber daya informasi. Dengan adanya internet dapat menghubungkan perangkat satu sama lain untuk saling bertukar data dari mana saja dan kapan saja. Dengan diadakannya kegiatan pelatihan ini, kami membagikan pengetahuan yang lebih dalam terkait penggunaan Google Classroom untuk presensi online, mengerjakan tugas, membuat dan menyerahkan tugas menggunakan alat pengolahan dokumen online. Berdasarkan hasil pengujian maka dapat disimpulkan bahwa mitra sangat puas terhadap kegiatan pengabdian kepada masyarakat dengan hasil dari setiap pertanyaan yaitu memiliki persentase nilai kepuasan lebih dari $80 \%$. Kegiatan pengabdian kepada masyarakat ini dapat memberikan ilmu pengetahuan tambahan kepada siswa-siswi terkait pembelajaran online khususnya dalam penggunaan aplikasi Google Classroom.
\end{abstract}

Kata Kunci: Google Classroom, Pandemi Covid-19, Aplikasi Digital, Pembelajaran Online, Pengabdian Masyarakat.

\section{Pendahuluan}

Perkembangan ilmu pengetahuan teknologi, informasi dan komunikasi saat ini telah berkembang cukup pesat, sehingga sangat berdampak bagi kehidupan manusia dalam segala aktifitasnya. Adanya pandemi Covid-19 yang dialami seluruh negara di belahan dunia, peran teknologi, khususnya dalam bidang pendidikan, sangat berpengaruh dalam mempermudah segala kebutuhan dalam proses belajar mengajar (Dimyati A et al. 2018).

Proses kegiatan belajar mengajar pada hakikatnya merupakan sebuah bentuk edukasi, yang menjadikan adanya suatu interaksi dua arah, yaitu adanya komunikasi antara pengajar dengan siswa-siswi (Pane dan Darwis Dasopang 2017).

Peranan teknologi informasi dan komunikasi pada dunia pendidikan adalah sebagai sumber ilmu pengetahuan dan juga alat bantu pembelajaran serta menjadi bagian yang penting dalam upaya peningkatan mutu (I Gede Agus Krisna Warmayana 2018). 
Aktifitas pembelajaran secara online atau biasa dikenal dengan sebutan daring (dalam jaringan) yang memanfaatkan perkembangan ilmu pengetahuan dan teknologi dapat dilakukan dengan adanya konektifitas jaringan internet dan mampu mempertemukan siswa-siswi dengan pengajar, yang pada pelaksanaannya, pembelajaran daring memerlukan dukungan perangkat mobile seperti smartphone, laptop, komputer, tablet, iphone, dan digunakan untuk mengakses informasi kapan saja dan dimana saja (Meda Yuliani et al 2020).

Pemanfaatan media pembelajaran dalam jaringan sudah banyak digunakan oleh lembaga pendidikan, contohnya yang ada pada kampus IHDN Denpasar untuk meningkatkan mutu pembelajaran (Wulandari 2021).

Google Classroom adalah salah satu media pembelajaran dalam jaringan yang saat ini sedang berkembang dan mulai digunakan. Aplikasi ini digunakan untuk pembelajaran dalam jaringan yang dapat dilakukan dari jarak jauh sehingga mempermudah pengajar dalam membuat, mengelompokkan dan membagikan tugas. Selain itu pengajar dan siswa-siswi dapat melakukan kegiatan pembelajaran melalui ruang kelas Google Classroom tanpa batasan tempat dan waktu dimana siswa-siswi juga dapat belajar, menyimak, membaca dan mengirim tugas dari jarak jauh.

Fitur-fitur penggunaan Google Classroom diantaranya: pengajar dapat mengirimkan tugas berbentuk dokumen, photo, slide ataupun video pembelajaran kepada siswa-siswi, pengajar dapat memberikan penilaian secara langsung dari tugas yang telah diberikan serta informasi dapat dipublikasikan oleh pengajar ke dalam kelas dan dapat dikomentari oleh siswa-siswi yang memungkinkan adanya interaksi dua arah antara pengajar dan siswa-siswi.

Kegiatan pengabdian pada masyarakat ini berfokus pada pelatihan tentang cara penggunaan Google Classroom di Yayasan Rahmatan Lil-Alamin Jakarta Timur. Dengan harapan, adanya peningkatan pengetahuan dan keterampilan para siswa-siswi mengenai penggunaan aplikasi Google Classroom sebagai media pembelajaran selama pandemi, yang dapat meningkatkan efektifitas kegiatan belajar mengajar dan mutu pendidikan dengan memanfaatkan perkembangan teknologi (Utami dan Vinsensia 2021).

Pemberlakuan pembatasan kegiatan masyarakat yang diatur oleh pemerintah, diberlakukan di seluruh daerah berdampak juga pada dunia pendidikan yaitu kebijakan belajar dari rumah (study from home). Oleh karenanya pelatihan pembelajaran secara dalam jaringan saat ini sangatlah diperlukan. Permasalahan pada Yayasan Rahmatan Lil-Alamin Jakarta Timur yakni adalah masih belum menggunakan Google Classroom untuk media pembelajaran dalam jaringan, selama ini pemberian materi dan pemberian tugas dari pengajar berlangsung dengan media komunikasi seperti WhatsApp group atau dikirimkan melalui email. Setelah tugas tersebut selesai dikerjakan oleh siswasiswi, dikirim kembali melalui email. Cara ini kami nilai kurang efektif baik bagi pengajar ataupun siswa-siswi. Tenaga pengajar di yayasan pun demikian, tidak dapat memanfaatkan dengan baik adanya Google Classroom yang dapat membantu dalam proses pembelajaran secara dalam jaringan.

1.1 Tujuan kegiatan ini adalah untuk melatih siswa-siswi di Yayasan Rahmatan Lil-Alamin menggunakan Google Classroom sehingga mampu mengimplementasikannya dalam proses belajar menagajar di yayasan.

1.2 Manfaat yang diharapkan dari pelatihan ini adalah untuk meningkatkan pengetahuan dan keterampilan siswa-siswi di Yayasan Rahmatan Lil-Alamin mengenai penggunaan aplikasi Google Classroom sebagai media pembelajaran selama pandemi covid-19.

1.3 Luaran yang diharapkan yaitu menambah pengetahuan serta meningkatkan kemampuan siswa-siswi dalam penggunaan aplikasi digital khususnya media Google Classroom untuk menunjang kegiatan belajar mengajar yang dilakukan secara dalam jaringan pada masa pandemi Covid-19. Pelatihan ini juga diharapkan dapat menjadi ilmu yang bermanfaat bagi siswa-siswi di Yayasan Rahmatan Lil-Alamin untuk pengembangan diri, dimana kami memberikan edukasi tersebut pada bulan November. Materi yang akan kami sampaikan adalah tentang pembelajaran secara online melalui media Google Classroom. Di dalam Google Classroom siswa-siswi dapat mengakses dengan mudah materi dan tugas yang diberikan berikut arsip pembelajaran atau penyimpanan data sehingga tidak perlu khawatir kehilangan data atau kerusakan dokumen karena semua terarsip secara rapih dan sistematis. 


\section{Realisasi Kegiatan}

\subsection{Bentuk Kegiatan dan Jadwal, Serta Tempat Kegiatan}

a. Metode Pelaksanaan Kegiatan

Pelaksanaan program dan kegiatan pelatihan penggunaan Google Classroom dibagi kedalam 2 kelompok siswa-siswi dengan tujuan agar penyampaian materi pelatihan mudah dipahami dan juga mengikuti protokol kesehatan pada masa pandemi Covid-19. Dimana pelaksanaan pelatihan tersebut dibagi kedalam 2 hari, yang masing-masing berdurasi 3 jam. Sebelum memulai pelatihan kami memberikan modul bahan ajar dalam bentuk hard cover yang menarik dan dalam proses pelatihan ini kami berikan pendampingan langsung kepada siswa-siswi untuk memudahkan dalam memahami materi yang diberikan.

b. Waktu Efektif Pelaksanaan Kegiatan

Kegiatan Pelaksanaan Pengabdian Kepada Masyarakat ini akan dilaksanakan pada Tanggal 6-7 November 2021 dengan rincian sebagai berikut:

Tabel 1. Jadwal Kegiatan Pengabdian Pada Masyarakat

\begin{tabular}{|c|l|c|c|c|c|}
\hline \multirow{2}{*}{ NO } & \multicolumn{1}{|c|}{ Kegiatan } & \multicolumn{3}{|c|}{ Jadwal Pelaksanaan Tanggal : } \\
\cline { 3 - 5 } & \multicolumn{1}{|c|}{$\mathbf{4}$} & $\mathbf{5}$ & $\mathbf{7}$ \\
\hline 1 & $\begin{array}{l}\text { Kunjungan ke Mitra Pengabdian } \\
\text { Masyarakat }\end{array}$ & & & \\
\hline 2 & $\begin{array}{l}\text { Persiapan Ruangan dan Peralatan } \\
\text { Pelatihan }\end{array}$ & & & \\
\hline 3 & Penyampaian Materi Pelatihan & & & \\
\hline 4 & Test/Latihan & & & \\
\hline
\end{tabular}

\section{c. Tempat Kegiatan}

Tempat pelaksanaan pengabdian kepada masyarakat ini beralamat: Jl. H. Naman No. 60 RT 12 RW 003, Kelurahan Pondok Kelapa, Kecamatan Duren Sawit, Kota Administrasi Jakarta Timur, Provinsi DKI Jakarta 13450

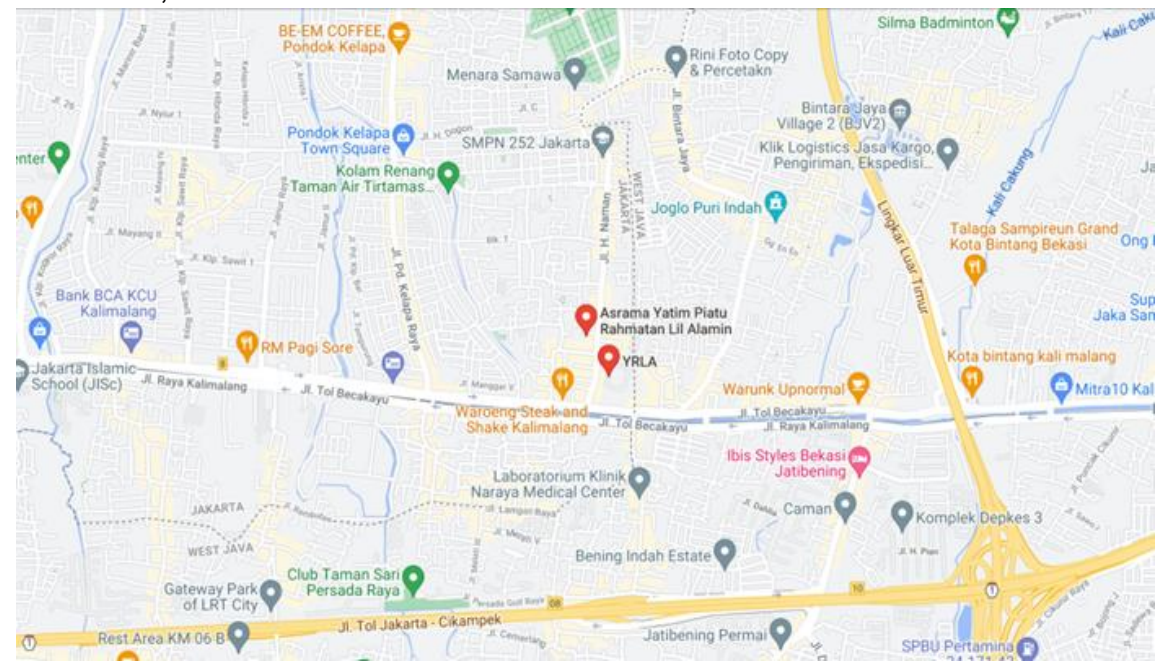

Gambar 1. Maps Lokasi 


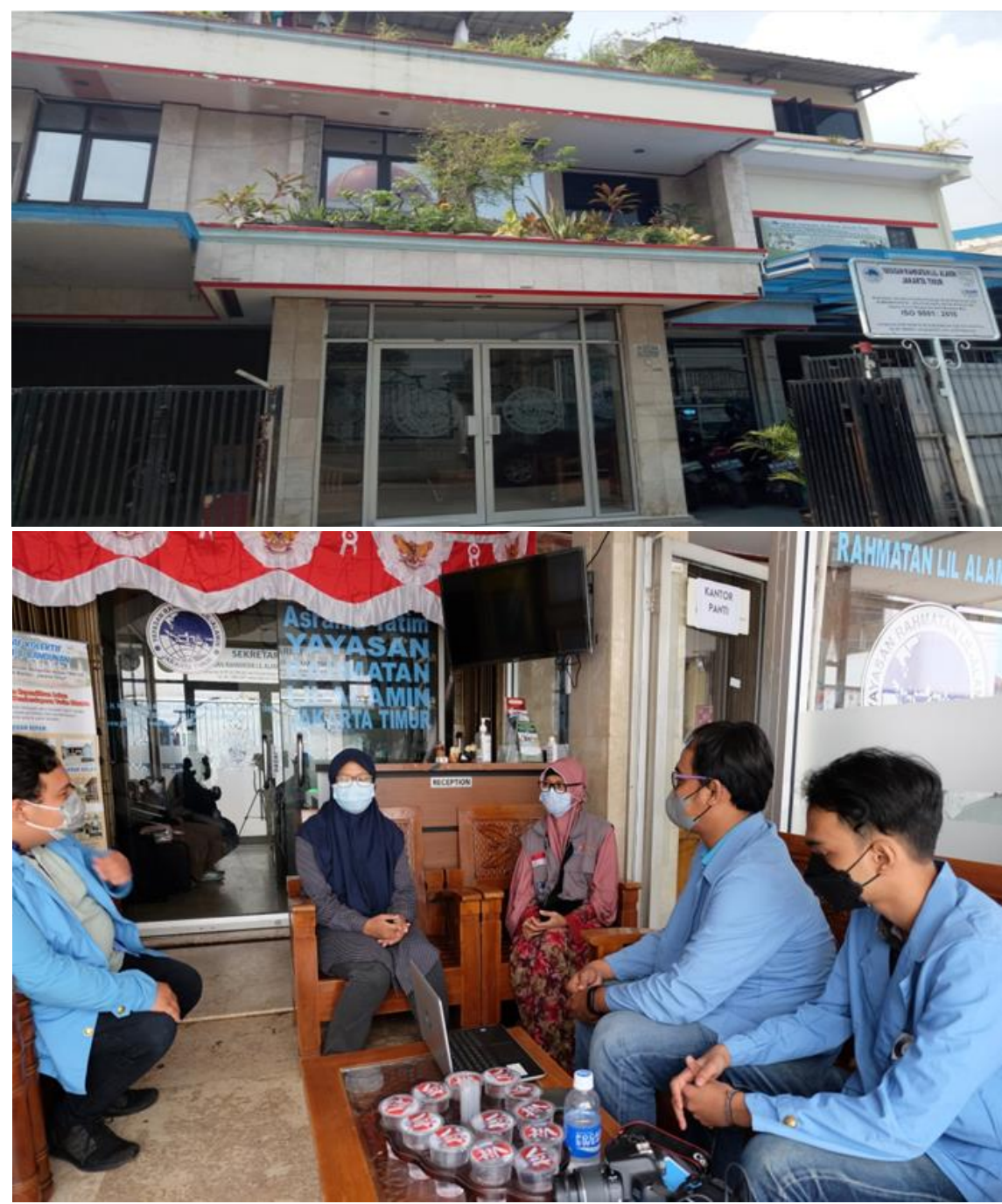

Gambar 1. Lokasi Pengabdian

\subsection{TIM Pelaksana Pengabdian dan TUPOKSI serta (Jam dan hari)}

\section{a. Susunan TIM Pengabdian}

Tabel 2. Susunan TIM Pengabdian

\begin{tabular}{|c|l|l|l|}
\hline No & \multicolumn{1}{|c|}{ Peran dalam TIM } & \multicolumn{1}{|c|}{ Tanggung jawab dalam TIM } & Dosen/Mahasiswa \\
\hline 1 & Tuti Haryanti, M.Kom & Penanggung Jawab dan Ketua Pengabdi & Dosen \\
\hline 2 & $\begin{array}{l}\text { Ryfhaza Rodia Rachman } \\
\text { Dapitandi Saputra } \\
\text { Rizieq Zikrila }\end{array}$ & Anggota Pengabdi & Mahasiswa \\
\hline
\end{tabular}

\section{b. Tugas Pokok Serta Peran Setiap TIM Pengabdian}

Tabel 3. Tugas Pokok TIM Pengbdian

\begin{tabular}{|l|c|c|c|c|}
\hline No & Nama Pekerjaan & Program & Volume (JKEM) & Pemateri \\
\hline \multicolumn{5}{|c|}{ Hari Pertama 06 November 2021 } \\
\hline
\end{tabular}




\begin{tabular}{|c|c|c|c|c|}
\hline No & Nama Pekerjaan & Program & Volume (JKEM) & Pemateri \\
\hline 1 & $\begin{array}{l}\text { - Masuk dan Bergabung } \\
\text { Dengan Kelas Pertama } \\
\text { Kalinya } \\
\text { - Presensi Online } \\
\text { - Mengerjakan Tugas } \\
\text { - Kuis Online } \\
\text { - Merubah Bahasa } \\
\text { - Menggunakan Google } \\
\text { Classroom Pada } \\
\text { Smartphone Android } \\
\text { - Membuka Email di } \\
\text { Smartphone }\end{array}$ & $\begin{array}{l}\text { - Login Google } \\
\text { Classroom dan masuk } \\
\text { kelas } \\
\text { - Mengisi Presensi online } \\
\text { di Google Form } \\
\text { - Mengerjakan dan } \\
\text { mengupload tugas } \\
\text { - Mengerjakan kuis } \\
\text { online } \\
\text { - Merubah bahasa pada } \\
\text { Google Classroom } \\
\text { - Mengakses Google } \\
\text { Classroom melalui } \\
\text { smartphone } \\
\text { - Mengakses email } \\
\text { melalui smartphone }\end{array}$ & 08:30 s.d 11:30 Wib & $\begin{array}{l}\text { Ryfhaza Rodia Rachman } \\
\text { Dapitandi Saputra } \\
\text { Rizieq Zikrila }\end{array}$ \\
\hline \multicolumn{5}{|c|}{ Hari Kedua 07 November 2021} \\
\hline 2 & $\begin{array}{l}\text { - Masuk dan Bergabung } \\
\text { Dengan Kelas Pertama } \\
\text { Kalinya } \\
\text { - Presensi Online } \\
\text { - Mengerjakan Tugas } \\
\text { - Kuis Online } \\
\text { - Merubah Bahasa } \\
\text { - Menggunakan Google } \\
\text { Classroom Pada } \\
\text { Smartphone Android } \\
\text { - Membuka Email di } \\
\text { Smartphone }\end{array}$ & $\begin{array}{l}\text { - Login Google } \\
\text { Classroom dan masuk } \\
\text { kelas } \\
\text { - Mengisi Presensi online } \\
\text { di Google Form } \\
\text { - Mengerjakan dan } \\
\text { mengupload tugas } \\
\text { - Mengerjakan kuis } \\
\text { online } \\
\text { - Merubah bahasa pada } \\
\text { Google Classroom } \\
\text { - Mengakses Google } \\
\text { Classroom melalui } \\
\text { smartphone } \\
\text { - Mengakses email } \\
\text { melalui smartphone }\end{array}$ & 08:30 s.d 11:30 Wib & $\begin{array}{l}\text { Ryfhaza Rodia Rachman } \\
\text { Dapitandi Saputra } \\
\text { Rizieq Zikrila }\end{array}$ \\
\hline
\end{tabular}

\subsection{Ringkasan Materi}

1) Masuk dan Bergabung Dengan Kelas Untuk Pertama Kalinya

a. Buka website https://mail.google.com/mail/ dengan akun gmail yang anda miliki, kemudian pilih Menu/Aplikasi Google, selanjutnya pilih Classroom.

b. Berikutnya, lakukan pendaftaran atau gabung kelas dengan cara mengklik tanda "+" (perhatikan tanda panah) dan klik "Gabung dengan kelas", masukan kode kelas yang diberikan oleh guru, kemudian klik "Gabung".

c. Bila berhasil Anda akan diarahkan pada laman dashboard kelas Anda. Berikut ini adalah penjelasan beberapa menu dan fitur pada dashboard Classroom.

\section{2) Mengisi Presensi Online}

a. Pada halaman utama, klik Tugas Kelas, kemudian pilih Presensi Online, selanjutnya klik link Presensi Online yang dibuat oleh guru Anda.

b. Bila berhasil akan diarahkan pada laman Presensi Online, selanjutnya Anda bisa langsung mengisi presensi tersebut, kemudian klik Kirim.

c. Jika berhasil akan muncul tampilan seperti ini.

\section{3) Mengerjakan Tugas}

a. Untuk memulai mengerjakan tugas, klik pada "Judul Tugas", kemudian klik "Lihat Tugas".

b. Setelah berhasil akan muncul halaman utama dari tugas yang diberikan, untuk mengerjakan tugas tersebut klik "+ Tambah atau buat". Selanjutnya pilih opsi pengerjaan yang tersedia pada Classroom. 


\section{4) Mengerjakan Kuis Online}

a. Jika guru anda memberikan kuis online, Anda dapat melihat kuis dengan cara lihat pada "Forum" atau "Tugas Kelas" kemudian pilih kuis yang diberikan oleh guru.

b. Kemudian akan muncul halaman yang berisi keterangan kuis dan link kuis. Selanjutnya pilih link kuis untuk membuka kuis yang harus dikerjakan.

c. Maka Anda akan dibawa menuju halaman kuis. Isi dengan teliti dan lengkap. Jika sudah lengkap dan yakin, maka pilih "Berikutnya".

d. Setelah itu akan muncul soal kuis yang harus Anda kerjakan. Ada beberapa tipe soal kuis yaitu pilihan ganda dan esay.

\section{5) Merubah Bahasa}

a. Buka aplikasi perambahan website (browser) pada komputer desktop Anda. Masuk ke laman http://www.classroom.google.com. Klik tombol buka kelas.

b. Login menggunakan Email dan password Classroom Anda. (lewati tahapan nomor ini bila Anda sudah melakukan login sebelumnya).

c. Pada halaman beranda Classroom, klik menu, pilih settings, kemudian klik "Google account settings", scroll mouse ke bawah, pada menu "Account preferences" klik "Language \& Input Tools" kemudian klik icon pensil pada pilhan menu Bahasa/Language untuk melakukan perubahan Bahasa, pilih Bahasa yang akan dipergunakan, kemudian klik "OK".

6) Menggunakan Google Classroom Pada Smartphone Andoroid

a. Buka/tap aplikasi Play Store pada Smartphone Anda.

b. Ketikan "Classroom" di menu pencarian.

c. Pilih Classroom kemudian tap tombol "Instal".

d. Untuk selanjutnya akan muncul laman pop up persetujuan, tap tombol "accept" untuk melanjutkan instalasi.

e. Setelah proses instalasi selesai, tap tombol "buka" atau "open" untuk membuka aplikasi Classroom.

f. Masukkan informasi akun Classroom Anda, tap tombol "Buka" atau "Sign In".

g. Kemudian tap "add another account" atau "tambahkan akun lain".

h. Pilih tombol "Existing" kemudian masukan informasi akun Classroom Anda berupa alamat email pada kolom yang tersedia, setelah itu masukan "password" atau "kata sandi", klik tombol "Berikutnya" untuk melanjutkan.

i. Ketika proses signing in berhasil Anda akan diminta persetujuan tentang Persyaratan Layanan dan Kebijakan Privasi, klik tombol "accept" atau "terima" untuk menyelesaikan proses masuk (sign in).

j. Ikuti tur Classroom dengan panduan atau sentuh "Lewati" atau "Skip" untuk membatalkannya.

\section{7) Membuka Email di Smartphone}

a. Tap aplikasi Email di Smartphone Anda.

b. Apabila sebelumnya Anda sudah login menggunakan Account Email lain, switch Account ke account Classroom Anda.

\subsection{Masyarakat Sasaran}

Peserta pengabdian masyarakat ini yaitu siswa-siswi Yayasan Rahmatan Lil-Alamin di Jakarta Timur yang berjumlah 20 orang.

\section{Tinjauan Hasil Yang Di Capai}

Berdasarkan hasil pengujian maka dapat disimpulkan bahwa mitra sangat puas terhadap kegiatan pengabdian kepada masyarakat dengan hasil dari setiap pertanyaan yaitu memiliki persentase nilai kepuasan lebih dari $80 \%$. 

berikut:

Keberhasilan pelaksanaan kegiatan pengabdian masyarakat ini dilihat dari tolak ukur sebagai

a. Respon positif dari mitra dan peserta yang telah diukur melalui observasi selama pelatihan berlangsung dan dari kuesioner yang diberikan didapatkan hasil dengan persentase nilai kepuasan lebih dari $80 \%$.

b. Hasil penilaian terhadap siswa-siswi didapatkan persentase nilai sebesar $65 \%$ dengan hasil yang cukup memuaskan, artinya materi pelatihan yang diberikan mampu diikuti dan dipahami oleh para peserta dengan baik.

c. Kegiatan pengabdian kepada masyarakat ini dapat memberikan ilmu pengetahuan tambahan kepada siswa-siswi terkait pembelajaran secara online khususnya dalam penggunaan aplikasi Google Classroom.

\section{Daftar Pustaka}

Dimyati A, Mohamad, Devit Suwardiyanto, Herman Yuliandoko, dan Vivien Arief W. 2018. "Pemanfaatan Teknologi Sebagai Media Pembelajaran Daring (on Line) Bagi Guru Dan Siswa Di Smk Nu Rogojampi." J-Dinamika : Jurnal Pengabdian Masyarakat 2(2):96-100. doi: 10.25047/j-dinamika.v2i2.565.

I Gede Agus Krisna Warmayana. 2018. "Pemanfaatan Teknologi Informasi Dan Komunikasi (TIK) Dalam Meningkatan Mutu Perguruan Tinggi Agama Hindu." Jurnal Penjaminan Mutu 4(2):219-26.

Meda Yuliani, et al. 2020. PEMBELAJARAN DARING untuk PENDIDIKAN. diedit oleh A. Rikki. Indonesia: Yayasan Kita Menulis.

Pane, Aprida, dan Muhammad Darwis Dasopang. 2017. "Belajar Dan Pembelajaran." FITRAH:Jurnal Kajian IImu-ilmu Keislaman 3(2):333. doi: 10.24952/fitrah.v3i2.945.

Utami, Yulia, dan Desi Vinsensia. 2021. "PkM: Peningkatan Efektifitas Pembelajaran Online Menggunakan Google Classroom." TRIDARMA: Pengabdian Kepada Masyarakat (PkM) 4(1):8-13.

Wulandari, Ida Ayu Gde. 2021. "Pemanfaatan Media Google Classroom Dalam Meningkatkan Mutu Pembelajaran Pada Masa Pandemi Covid-19 Di Ihdn Denpasar.” Jurnal Penjaminan Mutu 7(1):45-52. 


\section{Daftar Hadir}

Daftar Hadir Peserta kegiatan ini adalah sebagai berikut:

Presensl Peserta Pelatihan

Pemanfaatan Google Classroom Terhadap Siswa Pada Masa Pandemi Covid.19

Jakarta Timur, 07 November 2021

\begin{tabular}{|c|l|l|c|}
\hline Nomor & \multicolumn{1}{|c|}{ Nama Lengkap } & \multicolumn{1}{c|}{ Asal Sekolah } & Nomor HP \\
\hline 1 & Abdul Rohim & Rahmatan Lil-Alamin & \\
\hline 2 & Agus Prasetyo & Rahmatan Lil-Alamin & - \\
\hline 3 & Alya Nurdini & Rahmatan Lil-Alamin & - \\
\hline 4 & Asep Sulaeman & Rahmatan Lil-Alamin & - \\
\hline 5 & Bagus Perdana & Rahmatan Lil-Alamin & - \\
\hline 6 & Citra Wijayanti & Rahmatan Lil-Alamin & - \\
\hline 7 & Dafina Maulida & Rahmatan Lil-Alamin & - \\
\hline 8 & Ike Mustika Sari & Rahmatan Lil-Alamin & - \\
\hline 9 & Maulana Alfarid & Rahmatan Lil-Alamin & - \\
\hline 10 & Muhammad Ihsan & Rahmatan Lil-Alamin & - \\
\hline 11 & Nur Syamsiah & Rahmatan Lil-Alamin & - \\
\hline 12 & Rania Hafeeza K & Rahmatan Lil-Alamin & - \\
\hline 13 & Rio Hakim & Rahmatan Lil-Alamin & - \\
\hline 14 & Rudi Haemawan & Rahmatan Li-Alamin & - \\
\hline 15 & Sulistyaningsih & Rahmatan Li-Alamin & - \\
\hline 16 & Siti Aisyah & Rahmatan Lil-Alamin & - \\
\hline 17 & Siti Karmila & Rahmatan Lil-Alamin & \\
\hline 18 & Taufik Apriadi & Rahmatan Lil-Alamin & - \\
\hline 19 & Yunita & Rahmatan Lil-Alamin & - \\
\hline 20 & Zulkifli Hasan & Rahmatan Lil-Alamin & - \\
\hline
\end{tabular}

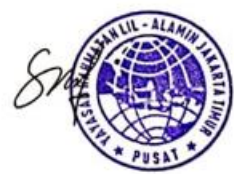

Pemanfaatan Google Classroom Terhadap Siswa Pada Masa Pandemi Covid-19 Di Yayasan Rahmatan Lil-Alamin Jakarta Timur (Ryfhaza Rodia Rachman, dkk) 


\section{Surat Keterangan dan Surat Tugas}

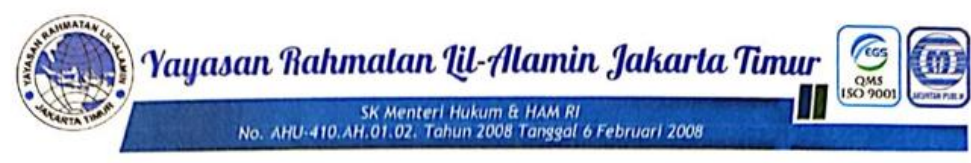

Nomor : 0432/2.3/YRLA/XII/2021

Perihal : Surat Keterangan Selesai Riset

\section{SURAT KETERANGAN}

Yang bertanda tangan di bawah ini :

$\begin{array}{ll}\text { Nama } & \text { : Ina Nurmayanti } \\ \text { Jabatan } & : \text { Sekretaris }\end{array}$

: Sekretaris

Dengan ini menerangkan bahwa, yang tersebut di bawah ini:
Nama
: Ryfhaza Rodia Rachman
: 11207539
Program Studi
Sistem

Adalah benar telah melakukan Riset pada Yayasan Rahmatan Lil-Alamin Jakarta

Timur pada tanggal 7 November 2021, dan yang bersangkutan telah melaksanakan tugasnya dengan baik dan penuh tanggung jawab.

Demikian surat keterangan ini dibuat dengan benar, untuk dapat dipergunakan sebagaimana mestinya.

akarta, 7 November 2021

(a)

Ina Nurmayanti

Sekretaris 


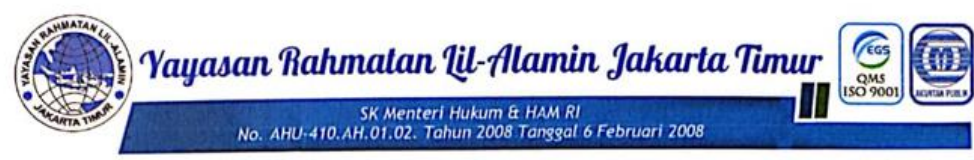

Nomor : 0431/2.3/YRLA/XII/2021

Perihal : Surat Keterangan Selesai Riset

\section{SURAT KETERANGAN}

Yang bertanda tangan di bawah ini :

$\begin{array}{ll}\text { Nama } & : \text { Ina Nurmayanti } \\ \text { Jabatan } & : \text { Sekretaris }\end{array}$

Dengan ini menerangkan bahwa, yang tersebut di bawah ini:

$\begin{array}{ll}\text { Nama } & : \text { Dapitandi Saputra } \\ \text { NIM } & : 11207663 \\ \text { Program Studi } & : \text { Sistem Informasi Universitas Nusa Mandiri }\end{array}$

Program Studi : Sistem Informasi Universitas Nusa Mandiri

Adalah benar telah melakukan Riset pada Yayasan Rahmatan Lil-Alamin Jakarta Timur pada tanggal 7 November 2021, dan yang bersangkutan telah melaksanakan tugasnya dengan baik dan penuh tanggung jawab.

Demikian surat keterangan ini dibuat dengan benar, untuk dapat dipergunakan sebagaimana mestinya.

4uevarta, 7 November 2021

(2) $\mid$

ina Nurmayanti

Sekretaris

The World Peace Foundation 


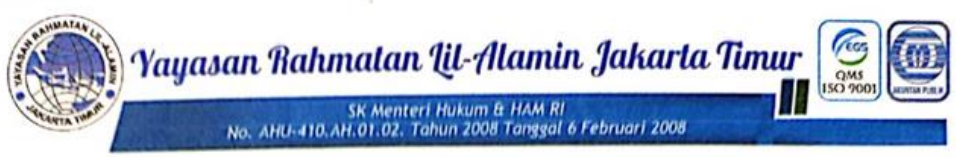

Nomor : 0433/2.3/YRLA/XII/2021

Perihal : Surat Keterangan Selesai Riset

SURAT KETERANGAN

Yang bertanda tangan di bawah ini :

$\begin{array}{ll}\text { Nama } & : \text { Ina Nurmayanti } \\ \text { Jabatan } & : \text { Sekretaris }\end{array}$

: Sekretaris

Dengan ini menerangkan bahwa, yang tersebut di bawah ini:

$\begin{array}{ll}\text { Nama } & : \text { Rizieq Zikrila } \\ \text { NIM } & : 11207716 \\ \text { Program Studi } & : \text { Sistem Informasi Universitas Nusa Mandiri }\end{array}$

Program Studi : :Sistem Informasi Universitas Nusa Mandiri

Adalah benar telah melakukan Riset pada Yayasan Rahmatan Lil-Alamin Jakarta Timur pada tanggal 7 November 2021, dan yang bersangkutan telah melaksanakan tugasnya dengan baik dan penuh tanggung jawab.

Demikian surat keterangan ini dibuat dengan benar, untuk dapat dipergunakan sebagaimana mestinya.

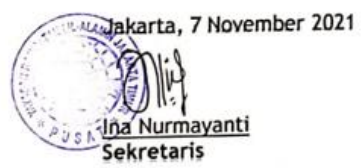

The World Peace Foundalion 


\section{Foto Kegiatan}

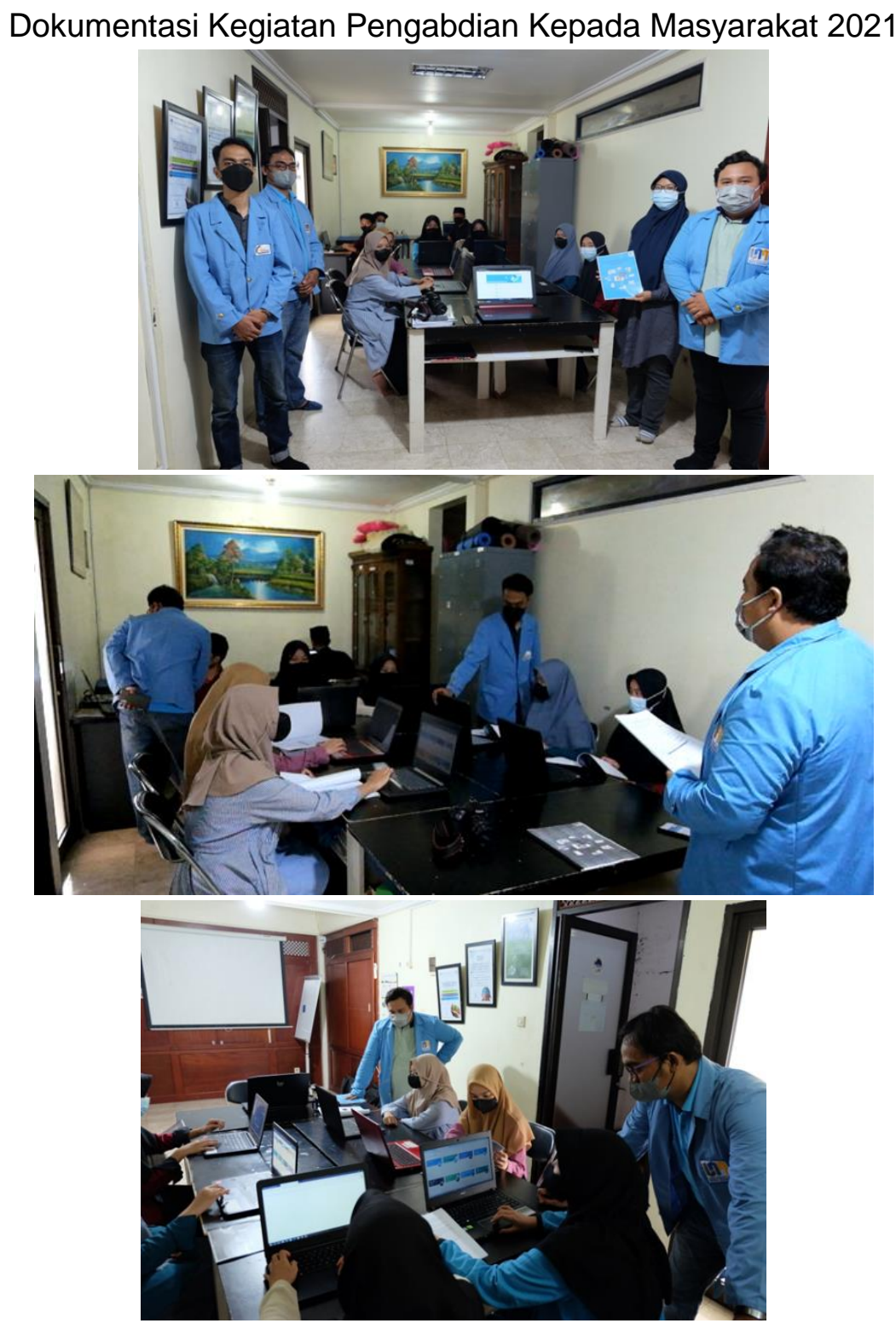

